\title{
Pengembangan Wisata Bahari di Pulau Raas dalam Rangka Menggerakkan Perekonomian Lokal
}

\author{
Icha Rizki Rifatussoliha, Khusairi Abdy, Muhfiatun, Abdul Wahid \\ Universitas Islam Negeri Sunan Kalijaga \\ muhfiatunassany@gmail.com
}

Submitted: $31^{\text {st }}$ July 2019. Revised: $11^{\text {th }}$ October 2019. Accepted: $31^{\text {st }}$ October 2019

Key word:

Marine Tourism;

Economic;

Archipelago;

Tour

Kata Kunci

Wisata Bahari;

ekonomi;

kepulauan;

wisata

\section{Abstract}

This community service aims to improve the potential of the archipelago, especially from the marine tourism sector. Against the background of not optimal management of tourism potential in the District of Raas which is an archipelago and has potential places to become a tourist. Development of Marine Tourism on Raas Island in Order to Mobilize the Local Economy. The process of developing marine tourism is done by mapping, observation, community empowerment and literature study. Based on the results of mapping and observation shows that there are 3 beaches that have attraction and are very potential, just need to be developed again and also managed properly. The three beaches also have different characteristics so that if the tours offered are not monotonous. The conclusion of the process of developing marine tourism is the need for awareness of the local community and also the cooperation of various parties and also agencies to work together to develop and build supporting facilities that can support these three potential beaches into a marine tourism that is not only a power pull Raas District alone, but also can be a pillar of the people's economy.

\section{Abstrak}

Pengabdian ini bertujuan untuk memprbaiki pengelolaan potensi wisata di Kecamatan Raas yang merupakan wilayah kepulauan dan memiliki tempat-tempat potensial menjadi sebuah wisata. Pengembangan potensi wisata bahari diharapkan mampu menjadi penggerak ekonomi lokal kepulauan Raas. Proses pengembangan wisata bahari ini dilakukan dengan melakukan pemetaan, observasi, pemberdayaan masyarakat dan studi pustaka. Berdasarkan hasil pemetaan dan observasi menunjukkan bahwa terdapat 3 pantai yang memiliki daya tarik dan sangat potensial, hanya saja perlu dikembangkan lagi dan juga dikelola dengan baik. Ketiga pantai tersebut memiliki perbedaan karakter, sehingga jika wisata yang ditawarkan tidak monoton. Kesimpulan dari proses pengembangan wisata bahari ini adalah perlu adanya kesadaran dari masyarakat lokal dan juga kerjasama dari berbagai pihak dan juga instansi untuk bahu-membahu mengembangkan dan membangun fasilitas-fasilitas pendukung yang dapat menunjang ketiga pantai potensial tersebut menjadi sebuah wisata bahari yang tidak hanya menjadi daya tarik Kecamataan Raas saja, tetapi juga bisa menjadi penopang perekonomian masyarakat. 


\section{PENDAHULUAN}

$$
\begin{array}{cccr} 
& \text { Pariwisata } & \text { adalah sebuah sektor } \\
\text { yang dapat dikembangkan dan }
\end{array}
$$
dioptimalkansebagai salah satu sumber pendapatan daerah pada umumnya dan pendapatan bagi masyarakat sekitar pada khususnya. Berlakunya UU No. 32 Tahun 2004 dan UU No. 33 Tahun 2004 dimana undang-undang tersebut memberikan otonomi yang lebih kepada Pemerintah Daerah untuk mengelola potensi yang ada di wilayahnya, dengan harapan membawa konsekuensi bertambahnya tanggung jawab dan tuntutan untuk mengembangkan dan menggali potensi sumber daya yang dimiliki daerah dengan tujuan menopang pembangunan di daerah, dengan adanya UU tersebut Pemerintah Daerah memiliki kebebasan dan lebih leluasa untuk mengembangkan obyek wisata.

Pengembangan sektor wisata merupakan inti pokok UU No. 10 Tahun 2009 tentang Kepariwisataan yang di dalamnya menjelaskan bahwa pemerintah berkolaborasi dengan lembaga yang terkait dengan sektor pariwisata menyelenggarakan penelitian dan pengembangan kepariwisataan dalam rangka memberikan dukungan pembangunan kepariwisataan (pasal $11 \mathrm{UU}$ No. 10 Tahun 2009). Pengembangan pariwisata di Indonesia bertujuan untuk mengurangi kemiskinan, melestarikan alam, lingkungan dan sumber daya, mengembangkan budaya, memperbaiki citra bangsa, dan memperkuat hubungan dengan negara lain (Sutawa, 2012).

Kamal (2014) menyatakan bahwa wisata bahari merupakan kegiatan yang dilakukan dengan tujuan menciptakan rasa senang, pengalaman baru, tantangan, dan kesehatan yang hanya dapat terwujud di wilayah perairan, serta diharapkan para wisatawan dapat berpartisipasi secara langsung dalam mengembangkan konservasi dan pelestarian lingkungan. Pemahaman mendalam mengenai asal usul ekosistem di daerah pesisir diharapkan dapat membentuk kesadaran msayarakat dalam melestarikan wilayah pesisir saat ini dan dimasa mendatang. Berbagai jenis kegiatan wisata di wilayah pesisir dan lautan dapat dimanfaatkan secara langsung maupun tidak langsung. Kegiatan langsung di antaranya renang, berperahu, diving, snorkeling dan memancing. Sedangkan wisata tidak langsung seperti olahraga pantai, piknik dan juga menikmati atmosfer laut (Gusti, 2011:29).

Akhir-akhir ini, sektor pariwisata tidak hanya dinikmati oleh golongan orang-orang berpenghasilan menengah ke atas, melainkan juga menjadi bagian penting dari kehidupan manusia, khususnya yang berkaitan dengan aktivitas 
ekonomi dan sosial. bahkan, pariwisata telah berkembang menjadi sebuah sektor industri terbesar di dunia, hal ini ditandai dengan peningkatan kunjungan dan pendapatan yang diperoleh dari wisatawan internasional. Berdasarkan rilis laporan World Tourism Organization (WTO), secara total kunjungan wisatawan di seluruh dunia dalam tiga tahun terakhir hampir mencapai 1 miliar orang per tahun (Nizar, 2011).

Kecamatan Raas merupakan salah satu kecamatan yang secara administratif merupakan wilayah Kabupaten Sumenep, Provinsi Jawa Timur, Indonesia. Yang mana dalam hal pengembangan ini, akan lebih mengutamakan pengembangan di Desa Ketupat, Kecamatan Raas, Sumenep, Jawa Timur. Desa Ketupat sendiri memiliki 4 Dusun yang memiliki karakteristik yang berbeda-beda. 4 dusun tersebut ialah Dusun Tengah, Dusun Noko, Dusun Keranji, dan Dusun Berlendur.

Analisis potensi pariwisata lokal yang ada di Desa Ketupat:
Letak Wilayah Menurut Desa Pantai dan Bukan Pantai Menurut Desa

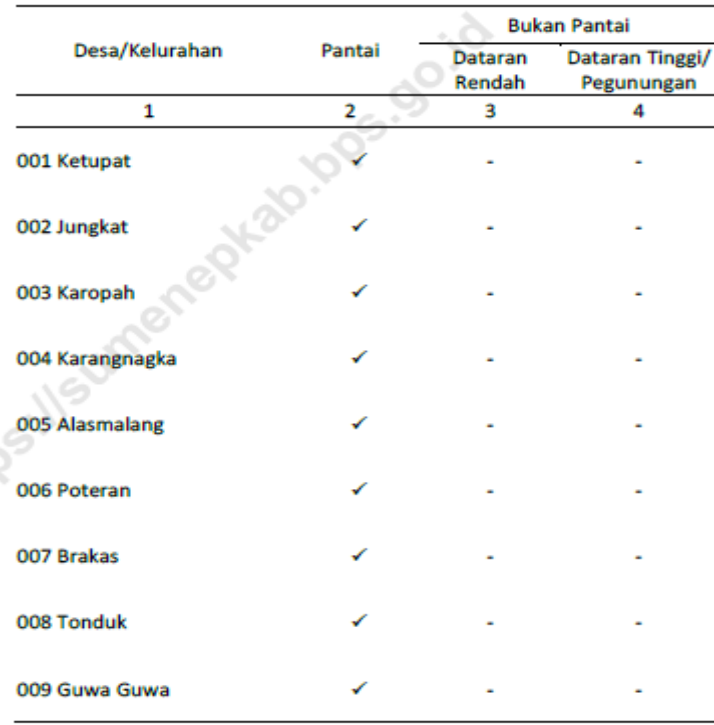

Gambar 1. Letak Wilayah Desa Pantai (sumber : BPS Sumenep.go.id)

Sebagai daerah kepulauan, Raas tentunya memiliki banyak pantai yang indah dan potensial untuk dikembangkan. Terutama untuk Desa Ketupat sendiri memiliki sedikitnya 3 pantai yang bisa dijadikan destinasi wisata yang bisa mendorong perekonomian desa. 3 pantai tersebut ialah Pantai Batur di Dusun Berlendur, Pantai Tanjung Wangi di Dusun Tengah, dan Pantai Pasir Panjang atau Beddhie Lancheng di Dusun Keranji.

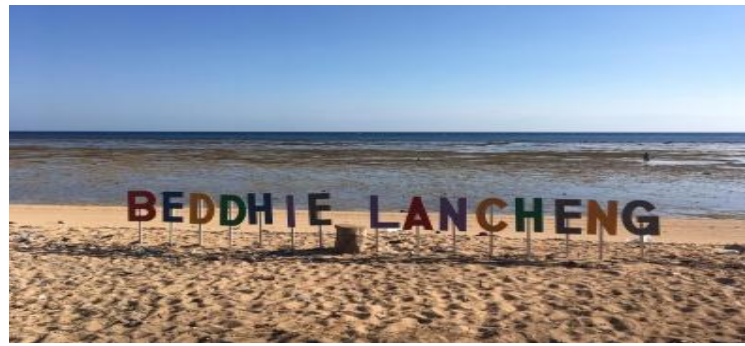

Gambar 2. Salah satu Ikon di Pantai Pasir Panjang 
Keindahan pantai yang sangat potensial untuk dikembangkan, sangat disayangkan bahwa pantai tersebut belum dikelola dengan baik. Banyak sampah berserakan, baik sampah laut maupun sampah pengunjung yang sesekali datang. Belum lagi permasalahan pengeboman laut guna keperluan mencari ikan dalam jumlah yang banyak dalam waktu yang singkat.

Dengan alasan tersebut, perencanaan dalam mengembangkan kawasan wisata bahari wajib dihubungkan dengan kepentingan-kepentingan pokok, dalam hal ini adalah pemberdayaan masyarakat pesisir. Masyarakat pesisir memiliki banyak pemahahaman tentang kondisi geografis dan sosial wilayahnya. Oleh sebab itu untuk mengembangkan kawasan wisata bahari, seharusnya dimulai dari pendekatan pada masyarakat sebagai salah satu upaya meningkatkan partisipasi dalam perencanaan yang memosisikan masyarakat setempat untuk berbagi, meningkatkan dan menganalisis pengetahuan masyarakat berkaitan dengan wisata bahari dan kehidupan pesisir, menyusun perencanaan dan tindakan untuk pengembangan wisata.

\section{Menurut Sastrayuda} Masyarakat pesisir merupakan masyarakat yang menggunakan hukum adat dan hidup secara tradisional di area pesisir maupun di luar kawasan. Pembangunan berbasis masyarakat lebih fokus kepada pemberdayaan (Empowerment), dimana potensi masyarakat merupakan sumber daya utama untuk pembangunan serta kebersamaan sebagai capaian dalam suatu proses pembangunan.

Irhamna (2017) menyatakan bahwa adanya peningkatan jumlah pengunjung maka secara langsung berdampak pada meningkatnya pendapatan retribusi obyek wisata yang nantinya juga akan berpengaruh pada bertambahnya Pendapatan Asli Daerah (PAD). Pendapatan retribusi yang didalamnya terdapat pendapatan restribusi wisata merupakan salah satu sektor yang paling berpengaruh dalam perolehan Pendapatan Asli Daerah, apalagi seperti Kabupaten Wonosobo yang memiliki potensi wisata sangat baik, ini tentunya harus lebih digalakkan dalam pengelolaan potensi tersebut sehingga dapat mencapai pendapatan daerah yang maksimal. Fitur dan pilihan produk pariwisata meliputi pengembangan produk pariwisata secara umum, diversifikasi paralel dan integrative serta sinergi tematik dan spasial antar produk (Benur \& Bill, 2015).

Beberapa penelitian telah dilakukan dengan topik yang sama yaitu terkait wisata bahari dan pengembangannya.

Diantaranya penelitian yang dilakukan oleh Irhamna (2017) yang 
berjudul "Dampak Pengembangan

Pariwisata Terhadap Perekonomian

Masyarakat Sekitar Objek Wisata di Dieng Kabupaten Wonosobo" menyimpulkan bahwa terjadinya perubahan yang signifikan terhadap objek wisata sesudah mengalami perubahan yakni meliputi fasilitas dan pelayanan, namun dari segi keamanan dan kebersihan masih tetap sama. Sementara itu dampak yang timbul terhadap perekonomian masyarakat sekitar obek wisata mengalami peningkatan pendapatan dan memperoleh kesempatan kerja.

Romadhon dan Rusmana (2017) dalam penelitiannya yang berjudul "Potensi Media Sosial Sebagai Sarana Media Promosi Pariwisata Berbasis Partisipasi Masyarakat" disimpulkan bahwa potensi media sosial sebagai sarana promosi dan pengembangan wisata berbasis partisipasi masyarakat sangat berpengaruh besar, masyarakat secara otodidak mampu dan memiliki potensi strategis dalam mempromosikan wisatanya. Jika masyarakat lebih memanfaatkan objekobjek wisata dan memanfaatkan potensi media sosial berbasis partisipasi masyarakat, maka nantinya pariwisata Indonesia mampu berkembang seperti Bali.

Nizar (2011) dalam penelitiannya yang berjudul "Pengaruh Pariwisata Terhadap Pertumbuhan Ekonomi di
Indonesia” disimpulkan bahwa 1) Pertumbuhan pendapatan dalam bidang pariwisata akan mendorong peningkatan dalam pertumbuhan ekonomi. 2) Pertumbuhan dalam bidang ekonomi memicu peningkatan pendapatan pariwisata secara cepat. 3) Di Indonesia antara pertumbuhan pariwisata dan pertumbuhan ekonomi secara langsung berjalan dengan hubungan timbal balik yang menghasilkan hubungan timbal balik yang saling menguntungkan. 4) Promosi wisata mampu memberikan pengaruh positif terhadap pertumbuhan pendapatan pariwisata.

Penelitian lain yang relevan terkait promosi guna pengembangan pariwisata dilakukan oleh Muhamad Sidiq Wicaksono, Dwi Yunitasari (2018) yang berjudul "Efektivitas Endorser Dalam Promosi Pariwisata Indonesia" menyimpulkan bahwa pemanfaatan sosial media melalui endorser memiliki dampak positif terhadap pariwisata di Indonesia, selain itu pemilihan artis dalam melakukan endorser juga sangat penting. Respon yang diterima masyarakat terhadap promosi pariwisata melalui endorser pesona Indonesia cukup baik, sehingga menghasilkan timbal baik yang kuat.

Nifita dan Arisondha (2018) dalam penelitiannya yang berjudul "Pengaruh Media Sosial Terhadap Minat Berkunjung Journal of Dedicators Community | 26 
Wisatawan di Taman Geopark Kabupaten Merangin" menyimpulkan bahwa 1) pemanfaatan media sosial sangat peenting dan menarik minat wisatawan, hal ini merupakan langkah strategis yang dapat dilakukan dalam menarik minat wisatawan.

2) Media sosial secara signifikan berpengaruh terhadap minat kunjungan wisatawan.

\section{METODE}

Metode yang digunakan dalam pengabdian ini adalah dengan:

1) Identifikasi potensi dan masalah. Kegiatan ini dilakukan dengan survey ke lokasi untuk melihat potensi, kondisi lingkungan dan masyarakat sekitar.

2) Pembelajaran pelestarian lingkungan kepada siswa-siswi SMA/SMP sebagai penggerak pariwisata

3) Kegiatan bersih pantai

4) Membuat kelengkapan sarana dan prasarana seperti papan petunjuk dan tulisan himbauan.

5) Penerapan strategi pemasaran wisata melalui media sosial.

\section{HASIL DAN PEMBAHASAN}

\section{Identifikasi Akar Permasalahan}

Daerah kepulauan merupakan daerah yang bisa menjadi tumpuan namun bisa juga menjadi ancaman bila masyarakatnya tidak bisa menjaga dan mengelola potensi yang ada. Seperti halnya di Kecamatan Raas tepatnya di Desa Ketupat ini, banyak potensi yang bisa dikembangkan guna pemasukan desanya. Misalnya dalam bidang kerajinan, masyarakatnya mampu membuat kerajianan yang beragam dan layak jual.

Hanya saja sebagian besar bekerja menjadi buruh dengan pendapatan yang tidak sebanding dengan harga kerja keras mereka. Hal ini dilatar belakangi oleh ketidaktahuan mengenai pengemasan, label, dan market untuk menyalurkan barang atau produk mereka. Dalam bidang pengolahan produk pun sama, masyarakatnya memiliki banyak potensi seperti di Dusun Berlendur terkenal dengan kopinya yang khas, di Dusun Karanji terkenal dengan olahan peyeknya yang renyah, namun tidak ada yang mengarahkan untuk memasarkan produk ini ke luar daerah sehingga hanya menjadi konsumsi masyarakat lokal saja. 




Gambar 3. Kerajinan Dreamcatcher karya warga Dusun Banlendur

Sementara dalam bidang pariwisata, banyak pantai yang indah dan layak untuk dikelola lebih lanjut. Namun dengan berbagai macam permasalahan daerah yang ada, hal-hal semacam inipun menjadi terabaikan. Pemerintah lebih fokus pada permasalahan pengadaan infrastruktur. Selain itu permasalahan pariwisata tidak hanya terhenti dari satu sisi saja, malainkan banyak hal.

\section{Pertama,}

ketidaksadaran masyarakat setempat untuk merawat pulaunya. Terlihat dari masyarakatnya yang suka membuang sampah sembarangan, pengeboman laut, serta meracun ikan yang dapat menyebabkan banyak permasalahan dan kerugian bagi mereka sendiri. Kedua, partisipasi pemerintah maupun warga desa yang kurang aktif dalam mengembangkan potensi yang ada. Saat melakukan agenda bersih-bersih salah satu pantai yang dikenal sangat indah di Kecamaatan Raas ini.

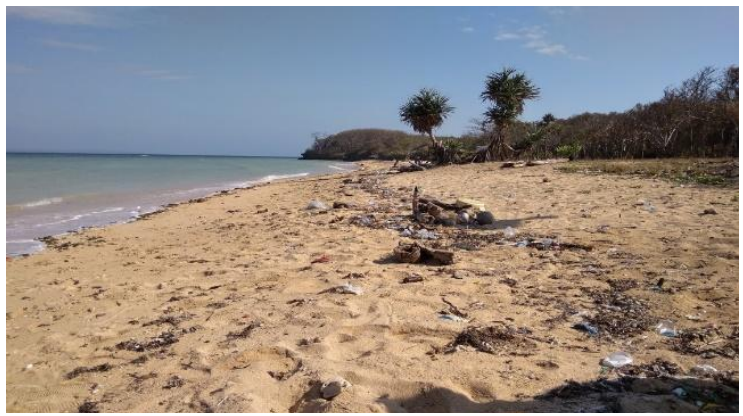

Gambar 4. Bersih-Bersih Pantai Pasir Panjang

Kali ini pemerintah dan beberapa warga ikut berpartisipasi, namun mereka hanya duduk dan mengawasi. Bahkan saat ada wisatawan yang datang dan turut membuang sampah air minum gelas plastik dan sebagainya mereka hanya maklum tanpa ada inisiatif untuk menegur atau mengehentikan aktifitas itu. Padahal hal itu bisa saja dilakukan, mengingat wisatawan sendiri berasal dari SMP desa sebelah (Desa Jungkat). Ketiga, tidak adanya keberpihkan pemerintah terhadap lingkungan. Terlihat dari tidak adanya peraturan yang tegas mengenai pengelolaan sampah, pelarangan pengeboman, dan sebagainya. Hal ini dilatar belakangi oleh beberapa oknum pemerintah yang juga menikmati hasil kegiatan pengeboman ataupun peracunan ikan laut. Tentu saja semua itu dapat mempengaruhi ekosistem biota laut yang nantinya akan berdampak kembali kepada masyarakat setempat.

Journal of Dedicators Community | 28 


\begin{tabular}{lll}
\hline Permasalahan infrastruktur berupa & harian warga setempat, misalnya disela- \\
jalan juga menjadi hambatan utama & sela kegiatan dzikir setelah shalat maghrib \\
pengembangan wisata. Karakteritik pantai & yang disampaikan oleh tokoh agama \\
Kecamatan Raas ialah pantainya dalam & setempat. Kemudian untuk anak usia \\
waktu-waktu tertentu akan surut dan & sekolah akan diberikan materi serta video \\
berubah menjadi laut yang sangat dangkal & mengenai dampak kerusakan lingkungan \\
sehingga menyulitkan kapal besar untuk & yang disebabkan oleh membuang sampah \\
menuju dermaga, terutama akses untuk & sembarangan baik di tanah terutama di laut, \\
Desa Ketupat yang akan dikembangkan & dampak melakukan pengeboman, dan hal- \\
lebih lanjut. Untuk mendatangkan & hal lain yang berkaitan dengan cara \\
pengunjung dari luar, maka harus & melestarikan lingkungan.
\end{tabular}
menunggu jadwal kapal yang tidak setiap hari berlayar. Sehingga hal ini tentunya akan kurang efisien bagi beberapa wisatawan. Belum lagi akases jalur darat yang sempit dan berbatu untuk menuju Pantai Pasir Panjang. Mobil biasa akan sulit untuk menjangkaunya, apalagi bus besar yang biasa digunakan untuk berwisata. Biasanya wisatawan yang datang ke daerah ini datang menggunakan mobil bak terbuka yang siap mengahadapi rintangan berupa jalan yang tidak beraspal, berbatu, dan sempit.

\section{Pengembangan \\ Wisata Kecamatan Raas \\ a. Pembelajaran \\ pelestarian \\ lingkungan}

Pertama akan dilakukan penyuluhan mengenai bahaya kerusakan lingkungan terhadap warga setempat. Penyuluhan ini 11

Gambar 5. Nonton bareng video pelestarian lingkungan

Selain itu, perlu adanya kerjasama dengan anggota TNI maupun Polri berupa permohonan pendirian pos-pos penjaga kelestarian pantai guna mengawasi pergerakan masyarakat setempat agar lebih tertib. Karena jika hanya mengandalkan warga, hal itu kurang dihiraukan oleh masyarakat setempat dan malah akan menimbulkan kericuhan antar dusun atau antar desa. Bahkan karena hal itu, sempat ada korban nyawa karena perselisihan tersebut.

\footnotetext{
dilakukan bersamaan dengan kegiatan
} 


\section{b. Pengembangan wisata.}

Membuka daerah wisata baru, dalam hal ini ialah Pantai Tanjung Wangi serta penambahan beberapa fasilitas seperti ayunan dan lain-lain. Guna menarik wisatawan masuk, maka akan dikembangkan beberapa fasilitas pendukung seperti fasilitas kamar mandi, pendopo, dan tempat parkir. Untuk fasilitas spot foto lainnya juga ditambahkan melihat karakteristik pantai Tanjung Wangi yang luas dan cocok untuk dijadikan tempat mencari sunrise atau sunset. Berikut gambaran masing-masing wisata yang akan dikembangkan.

\section{c. Pantai Tanjung Wangi}

Merupakan pantai yang terletak di Dusun Tengah dan memiliki kenampakan yang indah untuk sunrise maupun sunset. Karena pantai ini terhampar sangat luas jika pantai sedang surut. Biasanya pada jam 09.00 WIB sampai 11.00 WIB saat pagi hari maka pantai akan surut serta pada jam 16.00-20.00 WIB pantai akan surut. Akan menjadi daya tarik tersendiri jika pantai ini memiliki fasilitas tambahan seperti ayunan dan lain-lain. Ombak di pantai inipun terbilang cukup tenang dan ke dalaman airnya terbilang cukup dangkal sehingga aman untuk berenang ataupun menaiki sampan jika ingin berkeliling.
Fasilitas yang sudah tersedia sebelumnya ialah tidak ada sama sekali mengingat dahulunya pantai ini ialah pantai yang tidak dikelola sama sekali dan hanya dijadikan tempat WC umum bagi warga setempat. Sehingga tidak terdapat fasilitas apapun di lokasi ini.

Untuk akses jalan menuju lokasi juga terbilang mudah dan tidak terlampau jauh dari Pelabuhan Ketupat atau desa Ketupat. Untuk kendaraan pribadi dan bermotor, akses jalannya cukup bersahabat jika dibandingkan dengan pantai pasir panjang. Selain itu tempat parkir yang tersedia di sinipun sangat luas dan cocok untuk dijadikan spot foto. Karena terdapat hamparan rumput yang luas dan kering nampak seperti padang ilalang atau sejenisnya. Lokasi tempat parker inipun langsung bersebelahan dengan pantai yang akan dikembangkan lebih lanjut.

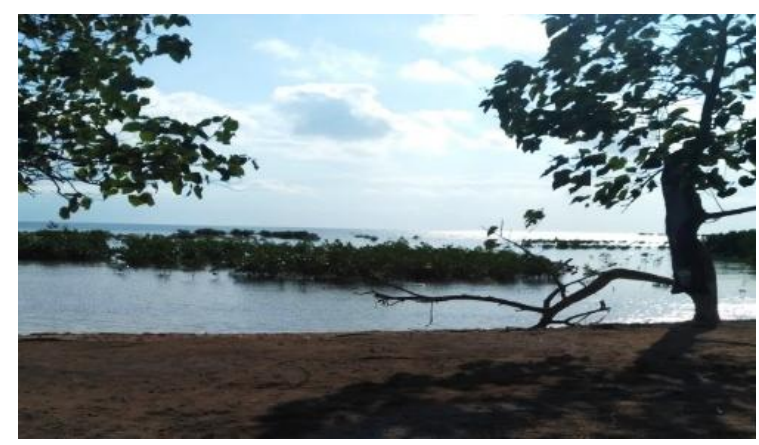

Gambar 6. Suasana Pantai Tanjung Wangi di pagi hari. 


\section{d. Pasir Panjang}

Untuk pantai pasir panjang, melihat karakteristiknya yang memang sudah menarik dan masih alami maka hanya akan dilakukan pembersihan area sekitar pantai dan ditambahkan beberapa pengadaan tempat sampah serta tulisan untuk membuang sampah pada tempatnya. Agar kesan kebersihan pantai tetap terjaga dan tidak menghilangkan kesan kealamian pantai.

Pantai ini sudah dikelola sebelumnya oleh perseorangan, sehingga untuk fasilitasnya sendiri, sudah terdapat beberapa tulisan penghias, pendopo, dan beberapa pohon yang memang sengaja diletakkan untuk duduk ataupun berfoto. Namun tidak terdapat tempat sampah sama sekali. Hal ini dikarenakan kebiasaan warga sekitar yang gemar membuang sampah sembarangan dan tidak adanya pengetahuan dan bekal yang cukup sejak masih berusia dini.

Untuk fasilitas pendukung lain seperti mushalla, kamar mandi, dan tempat parker juga akan ditambahkan. Mengingat saat liburan, pantai ini ialah pantai yang paling ramai dikunjungi oleh wisatawan. Sehingga akan sangat membantu jika disediakan beberapa fasilitas tersebut.

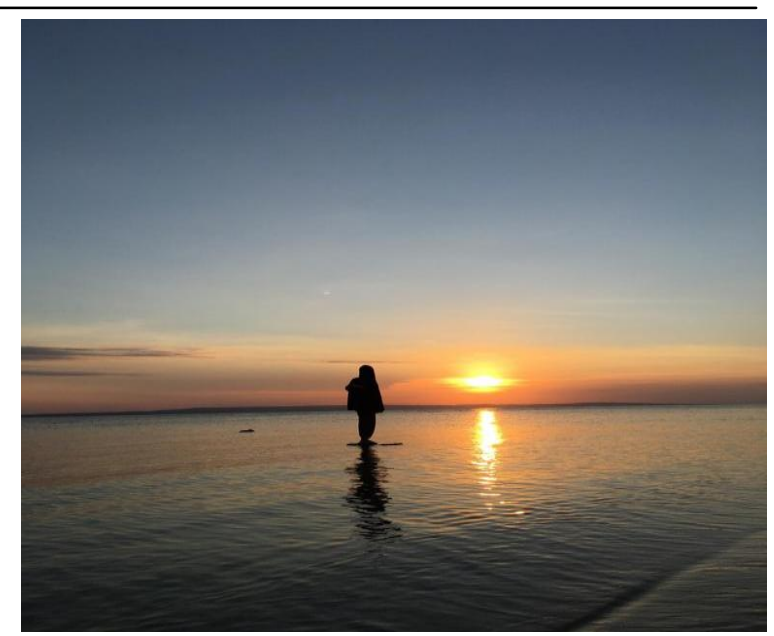

Gambar 7. Matahari terbenam di Pantai Pasir Panjang.

Rancangan prioritas pengembangan wisata bahari Desa Ketupat, Raas ialah menggunakan jalur air sebagai suatu hal yang baru (inovatif). Untuk menuju satu pantai ke pantai yang lain maka digunakan kapal berukuran sedang, dikarenakan akses jalan yang tidak memadai jika menggunakan akases jalur darat. Selain itu, untuk menciptakan keunikan serta daya tarik pariwisata di Kecamatan Raas ini, maka digunakan 2 jalur untuk menuju area pariwisata, yakni jalur darat dan air.

Untuk menuju pantai pasir panjang ini, karakteristik jalannya ialah jalan berbatu. Sehingga kurang ramah bagi mobil kendaraan pribadi yang hendak menuju lokasi. Untuk antisipasi, maka akan disediakan perahu yang menuju lokasi ini. Sehingga terdapat banyak pilihan untuk menuju lokasi ini. Untuk mobil bida diparkir di tempat Pantai Tanjung atau 
Pantai Brakas yang lebih ramah akses jalannya.

\section{e. Pantai Batur}

Pantai Batur merupakan salah satu pantai yang berada di Dusun Berlendur. Karakteristik pantai ini ialah pantai dengan batu karang. Pantai ini terkenal dengan gua yang berada di sisi pantai. Di dalam gua, sering dijadikan sebagai tempat bertapa bagi sebagian orang yang percaya dengan kekuatan gaib yang ada di wilayah tersebut. Saat sore hari, beberapa pemuda terlihat datang dan berkengkrama di pendopo yang disediakan di sekitar area pantai.

Akses jalan untuk menuju daerah ini terbilang cukup memadai. Sehingga cocok jika ingin dikembangkan lebih lanjut menjadi salah satu destinasi wisata bahari. Namun jika ingin mandi di pantai ini, keamanannya kurang terjaga dikarenakan karakteristik pantai yang berkarang. Pengembangan pantai ini bisa lebih diarahkan ke arah wisata menaiki sampan untuk berkeliling area sekitar pantai, atau snorkling guna melihat kondisi biota laut yang ada.

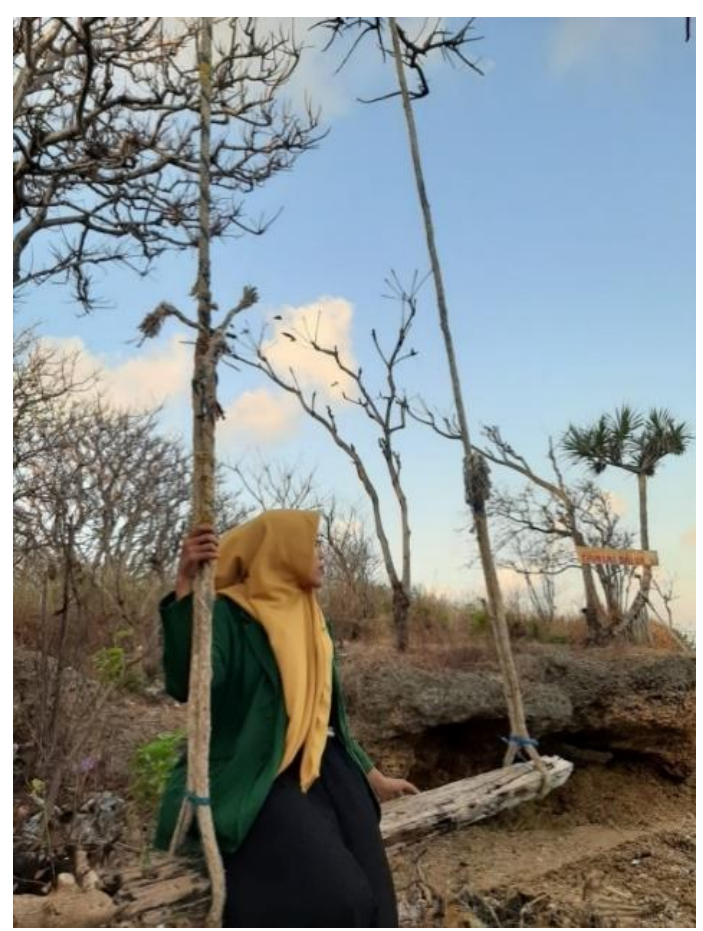

Gambar 8. Ayunan di Pantai Batur

Untuk fasilitas yang ada, hanya tersedia satu pendopo dan satu ayunan yang terbilang sangat bagus untuk spot foto, namun juga cukup terjal untuk menaikinya. Untuk mengatasi permasalahan ini, akan disediakan tangga untuk menaiki ayunan yang sudah tersedia sebelumnya.

\section{Strategi Dalam Menggerakkan Perekonomian Melalui Pariwisata}

Dalam rangka mengembangkan pariwisata daerah, maka beberapa strategi yang digunakan untuk mendatangkan wisatawan baik lokal daerah maupun luar daerah ialah : 


\section{a. Media Sosial}

Sebagaimana yang kita ketahui bersama bahwa media sosial memiliki dampak yang cukup besar dalam mempromosikan suatu produk. Media sosial yang biasa kita sebut sebagai jejaring sosial merupakan layanan berbasis website yang memberikan kesempatan setiap individu untuk membangun jaringan dan hubungan sosial melalui dunia maya. Sebagai contoh adalah pencitraan diri dengan membangun profil diri pengguna media sosial, menunjukkan jaringan seseorang dan menampakkan hubungan yang ada antara satu pemilik akun dengan pemilik akun lainnya dalam sebuah sistem media sosial, yang mana setiap jejaring sosial memiliki karakteristik dan sistem yang berbeda (Boyd dan Ellison: 2007). Contohnya seperti facebook, instagram, youtube, dan lain-lain.

Berdasarkan data pengguna sekitar 45 juta penduduk Indoensia menggunakan media sosial instagram secara aktif. Dari fakta tersebut, Indonesia memiliki komunitas instagram terbesar di Asia Pasifik, serta menjadi salah satu pasar terbesar di dunia (www.bisnis.tempo.co., 26 Juli 2017). Selain media sosial yang paling pengguna yaitu facebook, perkembangan pengguna instagram sangat besar. Jika ditelusuri lebih lanjut pada fitur pencarian di instagram dengan mengetik nama suatu wilayah atau daerah, bahkan negara, hasil pencarian yang muncul adalah destinasi wisata tempat tersebut. Akun media sosial tersebut dikelola baik oleh perseorangan, komunitas maupun institusi. Hal ini membuat para calon wisatawan dapat memperoleh informasi dengan mudah.

Pemasaran melalui media sosial termasuk dalam interactive marketing, sebab dalam media sosial memungkinkan adanya arus informasi timbal balik yang memungkinkan pemilik akun dapat berperan dan melakukan modifikasi isi dan bentuk informasi secara real time. Sedangkan partisipasi secara bahasa berarti ikut serta atau ikut ambil bagian (Willie Wijaya: 2004).

Dalam penelitian Nifita dan Edy (2018) Penggunaan media sosial adalah suatu hal yang penting untuk menarik minat wisatawan dalam mengunjungi taman Geopark Merangin hal ini di terbukti dari besarnya pengaruh penggunaan media sosial terhadap minat berkunjung adalah sebesar 42,2\%. Oleh karenanya, akan digunakan media sosial dalam hal ini You tube, Instagram, Facebook, dan lain sebagainya untuk menarik wisatawan.

\section{b. Kegiatan Besar}

Berkaca dari Pulau Tonduk yang berada di seberang Desa Ketupat, mereka sukses mempromosikan daerahnya dengan 
mengadakan event lomba dayung yang bekerjasama dengan berbagai pihak. Maka untuk tahap awal kagiatan besar ialah pembukaan pantai serta acara 17 -an yang akan dilakukan di sekitar pantai guna promosi dan acara 17-an Desa untuk yang pertama kalinya digelar, akan dilaksanakan di Pantai Tanjung Wangi yang nantinya akan dibuatkan film dokumenter dan berita kegiatan yang akan dikirim ke mediamedia cetak di Jawa Timur.

\section{c. Endorser}

Endorser dalam pemasaran pariwisata merupakan turunan dari sistem pemasaran tradisional yang menggunakan seseorang yang memiliki kredibilitas sesuai dengan produknya untuk mewakili citra dari produk yang dipromosikan. Selebriti sebagai endorser digunakan secara luas dalam mempromosikan sebuah produk. Indonesia sebagai salah satu destinasi wisata terbaik dan sebagai salah satu negara yang memiliki pengguna media sosial terbesar memiliki peluang untuk menggunakan media sosial sebagai wadah untuk mempromosikan pariwisata kepada wisatawan domestik.

Kementerian Pariwisata Republik Indonesia telah menjalankan program strategi pemasaran melalui media sosial pada tahun 2016. Pevita Pearce merupakan salah satu endorser dalam kampanye Pesona Indonesia yang memiliki target kepada wisatawan domestik.

Pevita telah mempromosikan tiga destinasi baru di Indonesia seperti Belitung, Banyuwangi, dan Raja Ampat. Analisis performa melalui akun Instagram pribadinya dilakukan untuk menilai tingkat kecocokan citra Pevita dengan destinasi yang diwakili. Akun Instagramnya memiliki respons yang baik dari pengikutnya tetapi Raja Ampat masih mengungguli destinasi lainnya dikarenakan citra yang sangat kuat dibandingkan destinasi lainnya. Tingkat kemenarikan fisik dari Pevita memiliki dampak positif dalam kampanye tersebut tetapi citra Pevita sebagai selebriti yang cantik tidak cocok dengan destinasi petualangan yang dia wakilkan (Wicaksono dan Dwi, 2018: 1)

\section{SIMPULAN}

Berdasarkan uraian di atas, dapat disimpulkan beberapa hal mengenai Pengembangan Wisata Bahari Daerah Kepulaan Kecamataan Raas Dalam Rangka Menggerakkan Perekonomian Lokal, yaitu:

1. Terdapat 3 pantai di Kecamataan Raas, khususnya Desa Ketupat yang memiliki potensi untuk dikembangkan lebih lanjut, yaitu Pantai Tanjung Wangi, Pantai Pasir Panjang dan 
Pantai Batur. Dimana masing-masing terdapat di dusun yang berbeda-beda.

2. Pengembangan wisata dilakukan dengan mengedukasi masyarakat lokal mengenai pentingnya menjaga lingkungan dan potensi yang terdapat di ketiga pantai tersebut. Kemudian dengan cara mengembangkan ketiga pantai tersebut dengan rincian sebagai berikut :

a. Pantai Tanjung Wangi, perlu adanya pembersihan dan pengadaan fasilitas-faslitas penunjang serta hiasan-hiasan untuk mempercantik pantai.

b. Pantai Pasir Panjang, cukup dibersihkan dengan rutin dan ditambahkannya tempat sampah di beberapa titik.

c. Pantai Batur, sudah cukup bersih, jadi hanya perlu ditambahkan beberapa fasilitas dan juga tangga untuk menaiki ayunan yang cukup tinggi.

3. Ketiga pantai tersebut juga butuh strategi pemasaran yang baik mengingat lokasinya yang terpencil. Strategi yang diusung yaitu melalui Media Sosial, Kegiatan besar dan juga Endorser.

\section{DAFTAR PUSTAKA}

Aghni, A., \& Hidayat, A. (2017). 45 Juta Pengguna Instagram, Indonesia Pasar Terbesar di Asia.

Boyd, D. M., \& Ellison, N. B. (2007). Social network sites: Definition, history, and scholarship. Journal of computer-mediated

Communication, 13(1), 210-230..

Irhamna, S. A. (2017). Dampak Pengembangan Pariwisata Terhadap Perekonomian Masyarakat Sekitar Objek Wisata di Dieng Kabupaten

Wonosobo. Economics

Development Analysis

Journal, 6(3), 320-327.

Kamal, I. S. (2014). Pengembangan Wisata Bahari Pulau Panambungan Kabupaten Pangkep dengan Pendekatan Aplikasi Desain Hemat Energi (Doctoral dissertation, Universitas Islam Negeri Alauddin Makassar).

Nifita, A. T., \& Arisondha, E. (2018). Pengaruh Media Sosial Terhadap Minat Berkunjung Wisatawan di Taman Geopark Kabupaten Merangin. Jurnal Manajemen Terapan dan Keuangan, 7(2), 169180. 
Nizar, M. A. (2011). Pengaruh Pariwisata Terhadap Pertumbuhan Ekonomi di Indonesia.

Sastrayuda, G. S. (2010). Konsep pengembangan kawasan desa wisata. Bandung (ID): Universitas Pendidikan Indonesia.

Sutawa, G. K. (2012). Issues on Bali tourism development and community empowerment to support sustainable tourism development. Procedia economics and finance, 4, 413-422.

Wicaksono, M. S., \& Yunitasari, D. (2018). Efektivitas endorser dalam promosi pariwisata

Indonesia. Jurnal Gama

Societa, 1(1), 1-8.

Wijaya, W. (2004). Kamus Lengkap

Inggris-Indonesia. Semarang:

Bintang Jaya. 